\title{
Blood urea measurement as a technique for assessing protein quality
}

\author{
By BJøRN O. EGGUM \\ Department of Physiology and Chemistry, Agricultural Research Laboratory, \\ Copenhagen, Denmark
}

(Received I6 fanuary 1970-Accepted 8 fune 1970)

\begin{abstract}
$x$. Three factors were investigated which influence blood urea content, namely the protein content in the diet, the time after feeding and the protein quality of the diet.

2. To investigate the relationship between the protein content in the diet and the blood urea content, seventeen experiments with rats given increasing amounts of protein in the diet were carried out. The experimental results show that there is a positive correlation $(r=0.95)$ between the protein content in the diet and the blood urea content.

3. For investigation of the influence of time after feeding on the urea content in the blood, a pig was used having a catheter in the portal vein for blood sampling at intervals. The results from this experiment showed that the blood urea content increases for the first $3-4 \mathrm{~h}$ after feeding and thereafter reaches a plateau.

4. To use blood urea measurement as a technique for assessing protein quality it is necessary to work under standardized conditions, especially in regard to the two factors just discussed.

5. Forty-two feeding-stuffs of widely differing quality were used in nitrogen balance trials with rats. The results showed that there is an inverse relation between the blood urea content and the biological value of the diet which is sufficiently accurate (coefficient of variation $=53 \%$ ) to provide a usefulmethod for the prediction of protein quality from measurement of urea levels.
\end{abstract}

The blood urea content is commonly considered in ruminants to reflect the protein quality of the diet, but this method has scarcely been used with monogastric animals. The use of blood urea levels as an index of protein quality depends on the control of several factors, some of which are discussed in this paper.

In experiments with growing rats and pigs, Münchow \& Bergner (1968) found a very high negative correlation between the biological value (Bv) of the feed and the blood urea content. The correlation coefficients were 0.99 and 0.96 for rats and pigs respectively, egg protein being used as a reference protein. Also, Münchow \& Bergner (rg68) found that the blood urea content increased with the protein content in the diet. In their experiments the urea content increased by 2.4 units each time the rats were supplied with another Io $\mathrm{mg}$ nitrogen/d, and they concluded that the blood urea content depends on both the quality and the quantity of the protein supplied in the diet. However, the same authors found no connexion between the weight of the animals and the blood urea content. Fonnesbeck \& Symons (1969), in experiments with horses, also showed that the blood urea content depends first on the protein quantity and quality in the diet, but can be affected also by renal failure. In experiments with suckling pigs, Pastuszewska (1967) obtained the same results. This relationship is consistent with the demonstration that an increase in protein content effects a decline in BV (Barnes, Bates \& Maack, 1946; Forbes, Vaughan \& Yohe, 1958; Nehring \& Haesler, 1954). Moreover, Miller \& Payne (196I) have quantified this effect so as to allow for variations in protein content in the prediction of the protein values of diets. 
Kornegay, Miller, Ullrey \& Hoefer (1964) found, as expected, that urea in large quantities in the diet causes an increase of the blood urea content. By means of synthetic amino acids, Kumta \& Harper (196r), in experiments with rats, demonstrated beautifully how amino acid imbalance raises the blood urea content, and how this can be reduced by restoring the amino acid balance. The urea content reached a maximum at $3 \mathrm{~h}$ after feeding. This dependence of blood urea content on time after feeding was verified in experiments with dogs by Anderson \& Edney (1969). However, they did not find a clearly defined maximum, but rather a steady increase up to $3 \mathrm{~h}$ and thereafter an almost constant level over the following $2 \mathrm{~h}$ when $8.5 \%$ protein was included in the diet. When the diet contained $5.0 \%$ protein the urea maximum in the blood was reached $2 \mathrm{~h}$ after feeding.

From this it appears that at least three factors influence the urea content, namely the quality and content of protein in the diet, and the time after feeding. By standardizing the technique it is possible to eliminate the effects of both protein content and time after feeding. In that way the protein quality should be the decisive influence on blood urea level.

\section{METHODS}

Blood urea levels were measured by Conway \& O'Malley's (1942) method, and the BV of protein was determined by a method previously described (Eggum \& Mercer, 1964).

\section{Effect of protein level}

Groups of five Wistar male rats weighing approximately $75 \mathrm{~g}$ were used in experiments in which the preliminary period lasted $4 \mathrm{~d}$ and the balance period $5 \mathrm{~d}$. Each animal received $150 \mathrm{mg} \mathrm{N}$ and Io $\mathrm{g}$ dry matter each day throughout the preliminary and the balance periods. The $\mathrm{N}$ content was adjusted by using a $\mathrm{N}$-free mixture constituted mainly of autoclaved potato starch, soya oil and minerals.

All blood samples were taken from the cervical vein at the end of the experiment, between 10.00 and I 1.00 hours. Any food or water left in the cage from the previous day was removed at 06.00 hours, i.e. $4-5 \mathrm{~h}$ before the blood samples were obtained.

Seventeen experiments were carried out, each of these on a group of five rats, in which increasing quantities of casein supplemented with $\mathrm{r} \%$ methionine were given. The crude protein content $(\mathrm{N} \times 6.25)$ in the diet was increased from 5 to $30 \%$ of dry matter.

\section{Effect of time after feeding}

Blood samples were taken from a pig $(68 \mathrm{~kg})$ immediately before feeding and then at intervals of $\mathrm{I} h$ after feeding, the samples being taken by a catheter in the portal vein. The test meal consisted of $1 \cdot 5 \mathrm{~kg}$ barley $+0 \cdot \mathrm{I} \mathrm{kg}$ casein.

\section{Effect of protein quaity}

In a further experiment, the relationship of the blood urea content with the protein quality in the diet was investigated. One group of five rats was used for experiments on each of forty-two feeding-stuffs. These included cereals, oilcake extracts, offal, 
fish meal, dried grass products and concentrates for pigs, poultry and ruminants. The experimental technique was exactly as described above, with all animals receiving I $50 \mathrm{mg} \mathrm{N}$ and Io $\mathrm{g}$ dry matter/d irrespective of the different diets.

\section{RESULTS}

The relationship between protein content in the diet and blood urea levels is shown in Fig. $x$. The regression equation being:

Blood urea $(\mathrm{mg} / \mathrm{ro0} \mathrm{ml})=6 \cdot 98+\mathrm{r} \cdot 07 \times$ crude protein $(\%)$,

$$
r=0.95 ; s=2.77 ; \quad s_{b}=0.09 \text {, }
$$

where $s=$ deviation from regression and $s_{b}=$ deviation of the regression coefficient.

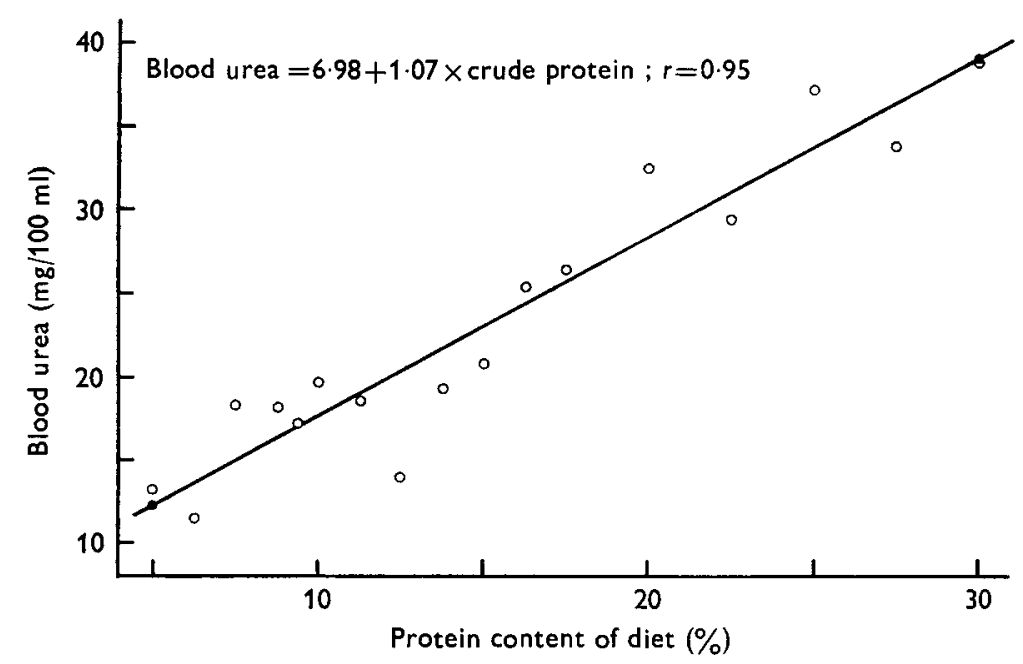

Fig. I. Blood urea content of rats in relation to the protein content in the diet.

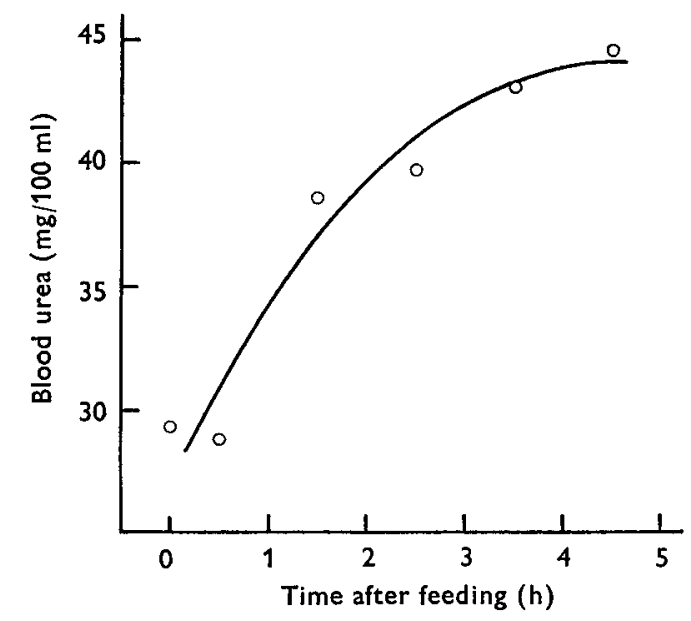

Fig. 2. Blood urea content of a pig in relation to time after feeding. 
The regression coefficient is significantly different from zero, as a $t$ test showed $P<0.001$. Thus urea content increases when the protein content in the diet increases. This is quite in agreement with the investigations referred to and must be taken into account if the blood urea content is to be used as a measure of the protein quality. Accordingly, all the experiments on the effect of protein quality were carried out using diets having the same level of protein.

Table I. Blood urea content in relation to the biological value of the proteins for rats

\begin{tabular}{lcc}
\multicolumn{1}{c}{ Feeding-stuff } & & Blood urea \\
Egg/I00 ml)
\end{tabular}

The results from the experiment on the pig are shown in Fig. 2. It will be seen that the blood urea content in the pig also depends on the time interval after feeding. With the diet used, i.e. barley and casein, it appears that at least $3-4 \mathrm{~h}$ may elapse before the 
blood urea content is constant, and suggests that $4-5 \mathrm{~h}$ after withdrawal of food should be a suitable time-period for a standardized test.

The results of the experiment on protein quality are shown in Table $\mathrm{I}$ in which the feeding-stuffs are tabulated according to their decreasing $\mathrm{BV}$. It is clear that there is a

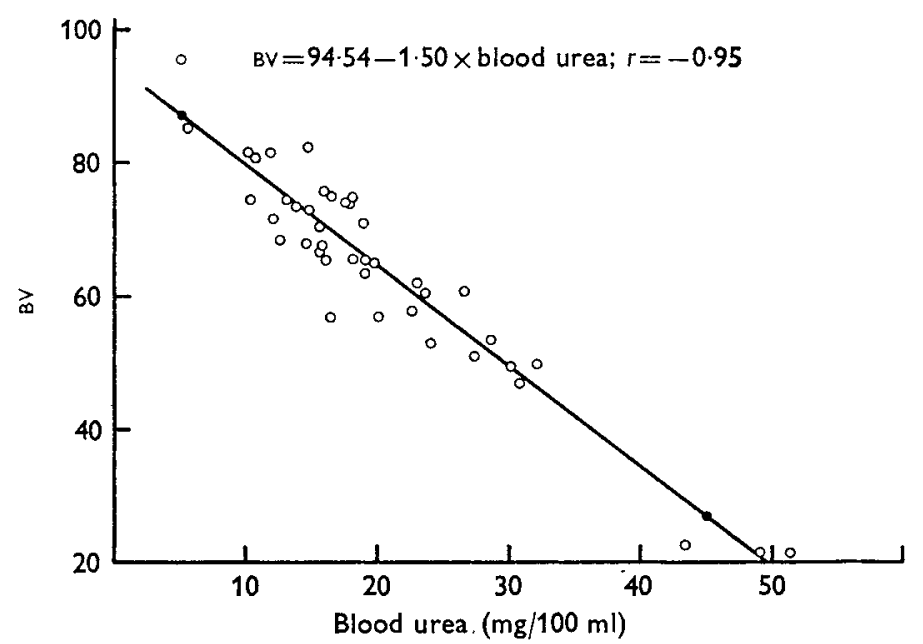

Fig. 3. Blood urea content of rats in relation to biological value (Bv) of the dietary protein.

direct relation between the blood urea content and the BV of the protein of the diet. The regression equation was calculated as:

$$
\begin{gathered}
\mathrm{BV}=94.54-\mathrm{I} \cdot 50 \times \text { blood urea }(\mathrm{mg} / \mathrm{ro0} \mathrm{ml}) ; \\
s=4.96 ; \quad s_{b}=0.08 ; \quad r=-0.95 .
\end{gathered}
$$

The regression coefficient differs significantly from zero, as a $t$ test showed $P<0.00$ r. Thus the equation shows that the content of blood urea decreases with increasing quality of the protein in the diet. This relationship agrees very well with the investigation of Münchow \& Bergner (1968).

The results for the forty-two samples investigated are shown graphically in Fig. 3 .

\section{DISCUSSION}

The results of these experiments confirm that the blood urea content increases as the protein content of the diet increases (Münchow \& Bergner, 1968; Fonnesbeck \& Symons, 1969; Pastuszewska, 1967). The significant relationship between the BV of the diet and the blood urea levels confirms the findings of Münchow \& Bergner (1968). It appears that a determination of the blood urea content could be a rapid and efficient method for evaluating protein quality. However, the experimental conditions must be kept very constant, especially in relation to the protein content of the diet and the time after feeding. 
Entitled to special thanks are Alice Klitz, technician, and Maja Rasmussen and Bente Anni Hansen, laboratory assistants, for careful analytical work and the calculations. Furthermore, thanks are due to Maja Rasmussen for translating the manuscript and drawing the figures.

\section{REFERENCES}

Anderson, R. S. \& Edney, A. T. B. (I969). Vet. Rec. 84, 348.

Barnes, R. H., Bates, M. J. \& Maack, J. E. (1946). F. Nutr. 32, 535.

Conway, E. J. \& O'Malley, E. (1942). Biochem. $\mathscr{~} .36,655$.

Eggum, B. O. \& Mercer, N. H. (1964). Ugeskr. Landm. no. 50.

Fonnesbeck, P. V. \& Symons, L. D. (1969). F. Anim. Sci. 28, 2 I 6.

Forbes, R. M., Vaughan, L. \& Yohe, M. (1958). F. Nutr. 64, 291.

Kornegay, E. T., Miller, E. R., Ulley, D. E. \& Hoefer, J. A. (1964). F. Anim. Sci. 23, 688.

Kumta, U. S. \& Harper, A. E. (196r). F. Nutr. 74, r 39.

Miller, D. S. \& Payne, P. R. (196I). Br. F. Nutr. I5, I I

Münchow, H. \& Bergner, H. (1968). Arch. Tievernähr. 18, 222.

Nehring, K. \& Haesler, E. (1954). Arch. Tierernähr. Suppl. no. 5, p. I 10.

Pastuszewska, B. (1967). Roczn. Naukroln. Ser. B 89, 4. 